\title{
The expression of TRAIL and its receptors in gastric cancer and the apoptotic effect of rh-TRAIL on SGC7901 cells
}

\author{
JIAN-KUN HU ${ }^{1}$, KUN YANG $^{1}$, CHUN-MEI LI $^{2}$, BO ZHANG ${ }^{1}$, \\ ZHI-XIN CHEN $^{1}, \mathrm{XIN}^{-Z U} \mathrm{CHEN}^{1}$ and JIA-PING CHEN ${ }^{1}$ \\ ${ }^{1}$ Department of Gastrointestinal Surgery, West China Hospital, Sichuan University, \\ No. 37 Guo Xue Xiang; ${ }^{2}$ Department of Gynecology and Obstetrics, West China Second \\ Hospital of Sichuan University, Chengdu 610041, Sichuan Province, P.R. China
}

Received October 24, 2008; Accepted December 10, 2008

DOI: $10.3892 /$ or_00000271

\begin{abstract}
This study investigated the expression of TRAIL and its receptors in human gastric cancer and normal gastric tissues, the effects of rh-TRAIL with or without chemotherapeutic drugs in apoptosis of the gastric cancer cell line SGC7901 and the expression changes of DR4 and DR5 in SGC7901 cells influenced by chemotherapeutic drugs. The expression of TRAIL, DR4 and DcR1 were studied in 34 cases of human gastric cancer tissues and 15 cases of adjacent normal mucosa tissues, as well as 21 cases of distant normal mucosa tissues by means of immunohistochemistry. In addition, the expression of FasL were studied in gastric cancer tissues by immunohistochemistry. The effects of treatment with rh-TRAIL alone and/or chemotherapeutic drugs on SGC7901 cell growth inhibition were measured by MTT assay and the mRNA changes of DR4 and DR5 were detected by RT-PCR technique. The expression of TRAIL, DR4 and DcR1 in gastric cancer were lower than those of normal tissues $(\mathrm{P}<0.05)$. There was significant relationship between the expression of TRAIL and Borrmann type of gastric cancer $(\mathrm{P}=0.039)$, and so was the expression of DcR1 and tumor location $(\mathrm{P}=0.01)$. The correlation coefficient between the expression of TRAIL and FasL was 0.354 $(\mathrm{P}=0.04)$. Rh-TRAIL protein had inhibiting effect on the growth of SGC7901 cells. DDP and 5-FU increased the growth-inhibiting ability of rh-TRAIL to SGC7901 cells. DDP facilitated the induction of expression of DR4 and DR5 significantly in cell line $(\mathrm{P}<0.05)$, but 5 -FU influenced only the expression of DR5 significantly. From the results, we concluded that the expression of TRAIL and its receptors were lower in gastric cancer than those of normal tissue, and
\end{abstract}

Correspondence to: Professor Jian-Kun Hu, Department of Gastrointestinal Surgery, West China Hospital, Sichuan University, No. 37 Guo Xue Xiang, Chengdu 610041, Sichuan Province, P.R. China E-mail: hujkwch@126.com

Key words: TNF-related apoptosis-inducing ligand, gastric cancer, apoptosis, chemotherapeutic drugs the apoptosis-inducing effect of rh-TRAIL was enhanced when concomitant with chemotherapeutic drugs.

\section{Introduction}

Gastric cancer is a disease with high incidence. It is estimated that 21,500 new cases of gastric carcinomas and 10,880 deaths will occur in the United States in 2008 (1). Since gastric cancer is often diagnosed at an advanced stage, posing a major challenge for healthcare professionals (2). Therefore, it is urgent to find new effective and comprehensive treatment methods. Research on inducing apoptosis to treat tumor has attracted great attention world-wide (3-6).

Tumor necrosis factor (TNF) and factor-associated suicide ligand (FasL) are important cytokines which trigger cell apoptosis, while TNF-related apoptosis-inducing ligand (TRAIL) is a member of the TNF superfamily, possessing potent anticancer activity without significant toxicity toward normal tissues (7). After its cloning by Wiley et al in 1995, TRAIL has been found to induce apoptosis in a wide variety of transformed cell lines of diverse origin (8). So far, 5 kinds of receptors have been found to bind with TRAIL specifically: death receptor 4 (DR4), death receptor 5 (DR5) conducting the signal of TRAIL-induced apoptosis, while TRAIL decoy receptor 1 and 2 (DcR1 and DcR2) and osteoprotegerin (OPG) can resist the TRAIL-induced apoptosis through preventing the conduction of the apoptosis signal $(9,10)$. The combinations of some chemotherapeutic drugs, such as cisplatin (DDP), adriamycin and paclitaxel, and TRAIL significantly enhanced the cytotoxic effect induced by TRAIL (11).

We investigated the expression of TRAIL, DR4 and DcR1 in human gastric cancer and normal gastric tissues, as well as the impact of TRAIL and/or chemotherapeutic drugs on apoptosis and the change of receptors (DR4 and DR5) of a gastric cancer cell line.

\section{Materials and methods}

Materials. Thirty-four primary gastric carcinoma tissues and 15 adjacent normal mucosa specimens $(2 \mathrm{~cm}$ away from the tumor) were obtained from patients who underwent 
gastrectomy for gastric cancer and the additional 21 distant normal tissues ( $5 \mathrm{~cm}$ away from the tumor) were also collected. Tissues were stored at $-70^{\circ} \mathrm{C}$ immediately after collection and the frozen full-thickness tissue samples were cut into $5-\mu \mathrm{m}$ sections. Then the 5- $\mu \mathrm{m}$ sections were lined on the glass slide with APES (Beijing Zhong Shan Biotechnological Inc., Beijing, P.R. China) and stored at $-20^{\circ} \mathrm{C}$.

The inclusion criteria were: gastric carcinoma confirmed by endoscopy and biopsy; patients had not received radiotherapy and chemotherapy preoperatively. The exclusion criteria were: concurrent tumors of other locations; history of previous malignancies; and adenocarcinoma contaminated with other types of tumors (such as adenosquamous carcinoma and lymphoma).

Tissue sections (4- $\mu \mathrm{m}$ thick) were prepared from paraffinembedded blocks for pathological evaluation. The histological grade was assessed by a pathologist. The primary tumors were staged according to the second English edition of Japanese Classification of Gastric Carcinoma (12).

The gastric cancer cell line (SGC7901) was kindly gifted by Dr Xiao-Mei Wang, Department of Gastroenterology, West China Hospital, Sichuan University, P.R. China.

Immunohistochemical staining. After placing at room temperature for $40 \mathrm{~min}$ and fixed in cold acetone for $10 \mathrm{~min}$, the sections were stained with labelled streptavidin/ peroxidase method (Beijing Zhong Shan Biotechnological Inc., Beijing, P.R. China) with the following primary antibodies (Santa Cruz Inc., USA): mouse monoclonal antibody TRAIL, goat polyclonal antibody DR4, goat polyclonal antibody DcR1 and rabbit polyclonal antibody FasL. After blocking endogenous peroxidase with $\mathrm{H}_{2} \mathrm{O}_{2}$ and non-specific binding sites with normal serum, the TRAIL, DR4, DcR1 and FasL antibody diluted at 1:100 was applied, and then the sections were incubated at $37^{\circ} \mathrm{C}$ for $40 \mathrm{~min}$ and $4^{\circ} \mathrm{C}$ overnight. After being washed with phosphate-buffered saline (PBS), biotinylated anti-IgG was applied onto the tissue sections and incubated at $37^{\circ} \mathrm{C}$ for $40 \mathrm{~min}$. Then $50 \mu 1$ of streptavidin/horseradish peroxidase was added dropwise and incubated at $37^{\circ} \mathrm{C}$ for $40 \mathrm{~min}$. The reaction product was visualized using DAB coloration fluid (Zymed Inc., USA). The sections were counterstained lightly with hematoxylin. Negative controls included parallel sections treated with PBS instead of the primary antibody, while the positive controls employed normal tissues of lymph nodes.

To minimize subjectivity, stained sections were reviewed and scored by two researchers, including a pathologist. Consensus between the two researchers were achieved in all cases. Patterns, cellular localization, staining intensity and percentage of positively expressed cells were recorded. The evaluation of expression was performed using a histochemistry score $(\mathrm{H})(13): \mathrm{H}=(\mathrm{i}+1) \mathrm{x} \mathrm{Pi}$. According to the staining intensity of tumor cells (i), the immunoreactions were graded as negative (0), faint yellow staining (1), or dark brown staining (2). Pi means the corresponding percentage of the positive cells. The final intensity of staining was defined as negative and positive, corresponding to $H$ values of $\leq 70$ and $>70$, respectively.

Cell culture. Gastric cancer SGC7901 cells were cultured in RPMI-1640 supplemented with $10 \%$ calf serum at $37^{\circ} \mathrm{C}$ with a humidified atmosphere containing $5 \% \mathrm{CO}_{2}$. The medium were changed every 48-72 h. Cells in logarithmic phase were used in all experiments.

MTT examination. The effects of TRAIL and chemotherapeutic drugs on the growth and survival of the human gastric cancer cell line were measured using 3-(4, 5dimethylthiazol-2-yl)-2, 5-diphenyl-tetrazolium bromide (MTT) (Sigma Inc., USA) assay. Using this method, we investigated the following two aspects:

1) SGC7901 cells were obtained to be cultured with recombinant human TRAIL (rh-TRAIL) (R\&D Inc., USA) of different concentrations in $2,4,8,10,15,20,25,50$ and $100 \mathrm{ng} / \mathrm{ml}$. The absorbance OD values were measured at 24 , 48, 72, 96 and $120 \mathrm{~h}$. Then the growth curve of SGC-7901 cells was drawn according to the inhibitory rates.

2) Cells were divided into six groups: i) control group with culture medium only, ii) cells plus rh-TRAIL alone, with the concentration in $2 \mathrm{ng} / \mathrm{ml}$ being used, iii) cells plus DDP $(2.5 \mu \mathrm{g} / \mathrm{ml})$ alone, iv) cells plus 5-fluorouracil (5-FU) $(50 \mu \mathrm{g} / \mathrm{ml})$ alone, v) cells plus rh-TRAIL $(2 \mathrm{ng} / \mathrm{ml})$ and DDP $(2.5 \mu \mathrm{g} / \mathrm{ml})$, vi) cells plus rh-TRAIL $(2 \mathrm{ng} / \mathrm{ml})$ and 5-FU. The absorbance OD values were measured at 24, 48 and $72 \mathrm{~h}$. The comparison among rh-TRAIL alone, anti-neoplastic drugs and rh-TRAIL plus antineoplastic drugs were performed.

Cell suspensions $\left(2.5 \times 10^{4} / \mathrm{ml}\right)$ were collected in $200 \mu \mathrm{l}$ medium in sterile 96-well flat-bottomed microtitre plates. Each group had four wells and four blank control wells. Plates would be incubated at $37^{\circ} \mathrm{C}$ in humidified air containing $5 \% \mathrm{CO}_{2}$. Fifteen $\mu 1$ solution of $5 \mathrm{mg} / \mathrm{ml} \mathrm{MTT}$ was added to each well. After another incubation for $4 \mathrm{~h}$ at $37^{\circ} \mathrm{C}, 150 \mu \mathrm{l}$ of dimethylsulfoxide (DMSO) was added and shaken for $10 \mathrm{~min}$. The OD values were measured by microplate spectrophotometer (Vector-1420) at $490 \mathrm{~nm}$. The inhibition rate of tumor cells for each drug with different concentrations was calculated as follows:

[1-(OD of drug-exposed well - OD of blank wells)/(OD of control well - OD of blank wells)] x100\%. The OD of both control and drug-exposed wells was adjusted by the OD of blank wells.

$R T-P C R$. To investigate the influence of different chemotherapeutic drugs on the expression of DR4 and DR5, RTPCR was performed to detect their expression. In this step, four groups of cells were used: i) control group without drugs, ii) cells plus DDP $(2.5 \mu \mathrm{g} / \mathrm{ml})$ alone, iii) cells plus 5-FU (50 $\mu \mathrm{g} / \mathrm{ml})$ alone, iv) cells plus adriamycin $(0.5 \mu \mathrm{g} / \mathrm{ml})$ alone.

Total RNA was isolated by using TRIzol reagent kit (Hua Shun Bioengineering Inc., Shanghai, P.R. China). To generate cDNA, $4 \mu 1$ RNA was first denatured at $70^{\circ} \mathrm{C}$ with $1 \mu 1$ Primer Oligo dT18 for 5 min before quenching on ice; then $2 \mu 1$ of each of the four deoxynucleotide triphosphates, $1 \mu 1$ ribonuclease inhibitor, and $5 \mathrm{X}$ reaction buffer $(4 \mu 1)$ were added together for $5 \mathrm{~min}$ incubation. Then $1 \mu \mathrm{l}$ of Revertiaid $^{\mathrm{TM}} \mathrm{M}-\mathrm{MuLv}$ reverse was added, and the reaction mix was incubated for $60 \mathrm{~min}$ at $42^{\circ} \mathrm{C}$.

Specific primers and probes for DR4 and DR5 and GAPDH were designed based on a previous report (14). For DR4, the forward primer was 5'-CTGAGCAACGCAGAC 
Table I. Characteristics of specimens and relationships between the expression of TRAIL, DR4, DcR1 and FasL and clinicopathological factors in gastric cancer.

\begin{tabular}{|c|c|c|c|c|c|c|c|c|c|c|c|c|c|}
\hline \multirow[b]{2}{*}{ Variable } & \multirow[b]{2}{*}{ Values } & \multicolumn{2}{|c|}{ TRAIL } & \multirow[b]{2}{*}{ P-values } & \multicolumn{2}{|c|}{ DR4 } & \multirow[b]{2}{*}{ P-values } & \multicolumn{2}{|c|}{ DcR1 } & \multirow[b]{2}{*}{ P-values } & \multicolumn{2}{|c|}{ FasL } & \multirow[b]{2}{*}{ P-values } \\
\hline & & $(+)$ & $(-)$ & & $(+)$ & $(-)$ & & $(+)$ & $(-)$ & & $(+)$ & $(-)$ & \\
\hline Gender & & & & 0.218 & & & 0.146 & & & 0.881 & & & 0.354 \\
\hline Female & 5 & 0 & 5 & & 1 & 4 & & 1 & 4 & & 3 & 2 & \\
\hline Male & 29 & 7 & 22 & & 16 & 13 & & 5 & 24 & & 11 & 18 & \\
\hline Age (yrs.) & $=12.82$ & & & & & & & & & & & & \\
\hline Borrmann type & & & & 0.039 & & & 0.567 & & & 0.386 & & & 0.802 \\
\hline I & 1 & 0 & 1 & & 0 & 1 & & 0 & 1 & & 0 & 1 & \\
\hline II & 6 & 1 & 5 & & 2 & 4 & & 0 & 6 & & 2 & 4 & \\
\hline III & 25 & 4 & 21 & & 14 & 11 & & 5 & 20 & & 11 & 14 & \\
\hline IV & 2 & 2 & 0 & & 1 & 1 & & 1 & 1 & & 1 & 1 & \\
\hline Tumor location & & & & 0.437 & & & 0.383 & & & 0.01 & & & 0.876 \\
\hline Upper third & 6 & 0 & 6 & & 3 & 3 & & 1 & 5 & & 2 & 4 & \\
\hline Middle third & 9 & 2 & 7 & & 3 & 6 & & 0 & 9 & & 3 & 6 & \\
\hline Lower third & 17 & 4 & 13 & & 9 & 8 & & 3 & 14 & & 8 & 9 & \\
\hline Whole stomach & 2 & 1 & 1 & & 2 & 0 & & 2 & 0 & & 1 & 1 & \\
\hline Tumor size & & & & 0.301 & & & 1 & & & 0.57 & & & 0.615 \\
\hline$\leq 5.0 \mathrm{~cm}$ & 12 & 2 & 10 & & 6 & 6 & & 1 & 11 & & 6 & 6 & \\
\hline$\sim 8.0 \mathrm{~cm}$ & 18 & 3 & 15 & & 9 & 9 & & 4 & 14 & & 6 & 12 & \\
\hline$>8.0 \mathrm{~cm}$ & 4 & 2 & 2 & & 2 & 2 & & 1 & 3 & & 2 & 2 & \\
\hline Differentiation & & & & 0.209 & & & 0.409 & & & 0.54 & & & 0.623 \\
\hline Signet cell & 3 & 0 & 3 & & 1 & 2 & & 0 & 3 & & 2 & 1 & \\
\hline Poorly & 24 & 4 & 20 & & 11 & 13 & & 4 & 20 & & 9 & 15 & \\
\hline Well-moderately & 7 & 3 & 4 & & 5 & 2 & & 2 & 5 & & 3 & 4 & \\
\hline Depth of infiltration (T) & & & & 0.819 & & & 0.636 & & & 0.596 & & & 0.069 \\
\hline $\mathrm{T} 1$ & 3 & 1 & 2 & & 2 & 1 & & 0 & 3 & & 3 & 0 & \\
\hline $\mathrm{T} 2$ & 3 & 1 & 2 & & 2 & 1 & & 0 & 3 & & 0 & 3 & \\
\hline $\mathrm{T} 3$ & 27 & 5 & 22 & & 13 & 14 & & 6 & 21 & & 11 & 16 & \\
\hline $\mathrm{T} 4$ & 1 & 0 & 1 & & 0 & 1 & & 0 & 1 & & 0 & 1 & \\
\hline Nodal status (N) & & & & 0.429 & & & 0.08 & & & 0.737 & & & 0.206 \\
\hline No & 13 & 4 & 9 & & 8 & 5 & & 2 & 11 & & 7 & 6 & \\
\hline $\mathrm{N} 1$ & 7 & 2 & 5 & & 5 & 2 & & 2 & 5 & & 4 & 3 & \\
\hline $\mathrm{N} 2$ & 11 & 1 & 10 & & 2 & 9 & & 2 & 9 & & 3 & 8 & \\
\hline N3 & 3 & 0 & 3 & & 2 & 1 & & 0 & 3 & & 0 & 3 & \\
\hline Distal metastasis (M) & 4 & 1 & 3 & $1^{\mathrm{b}}$ & 3 & 1 & $0.601^{\mathrm{b}}$ & 1 & 3 & $0.559^{\mathrm{b}}$ & 1 & 3 & $0.627^{\mathrm{b}}$ \\
\hline Peritoneal metastasis $(\mathrm{P})$ & 5 & 1 & 4 & $1^{\mathrm{b}}$ & 3 & 2 & $1^{\mathrm{b}}$ & 2 & 3 & $0.205^{\mathrm{b}}$ & 3 & 2 & $0.627^{\mathrm{b}}$ \\
\hline Stage $^{a}$ & & & & 0.848 & & & 0.135 & & & 0.718 & & & 0.122 \\
\hline Ia & 3 & 1 & 2 & & 2 & 1 & & 0 & 3 & & 3 & 0 & \\
\hline $\mathrm{Ib}$ & 3 & 1 & 2 & & 2 & 1 & & 0 & 3 & & 0 & 3 & \\
\hline II & 6 & 2 & 4 & & 3 & 3 & & 2 & 4 & & 3 & 3 & \\
\hline IIIa & 5 & 1 & 4 & & 4 & 1 & & 1 & 4 & & 3 & 2 & \\
\hline IIIb & 9 & 1 & 8 & & 1 & 8 & & 1 & 8 & & 2 & 7 & \\
\hline IV & 8 & 1 & 7 & & 5 & 3 & & 2 & 6 & & 3 & 5 & \\
\hline
\end{tabular}

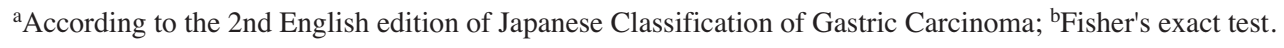

TCGCTGTCCAC-3', and the reverse primer was 5'-TCC AAGGACACGGCAGAGCCTGTGCCAT-3', while the forward primer and reverse primer for DR5 were 5'-GCC TCATGGACAATGAGATAAAGGTGGCT-3' and 5'-CCA
AATCTCAAAGTACGCACAAACGG-3' respectively. For GAPDH, the forward primer and reverse primer were 5'-CGG AGTCAACGGATTTGGTCGTAT-3' and 5'-AGCCTTCTC CATGGTGGTGAAGAC-3', respectively. 

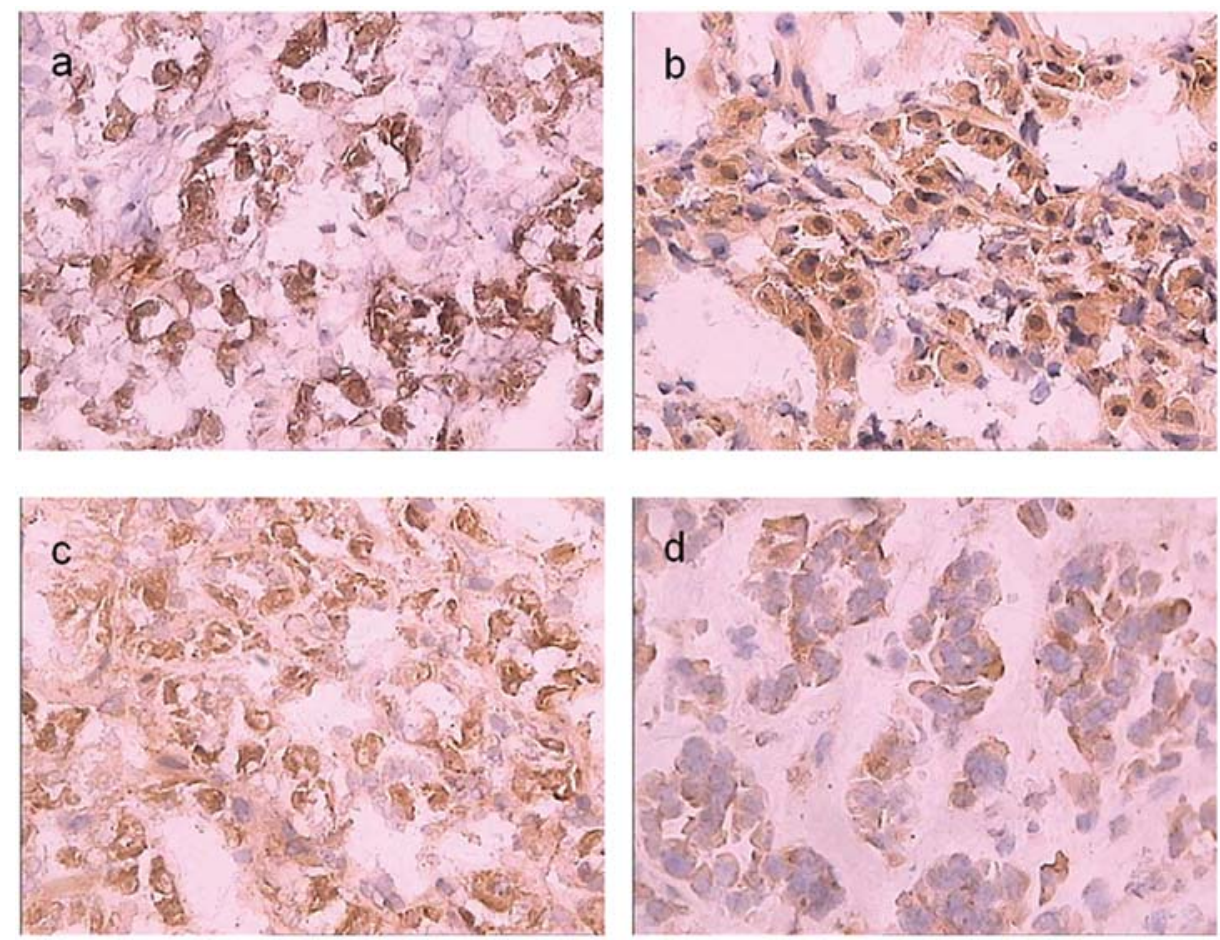

Figure 1. Immunohistochemical staining for TRAIL, DR4 and FasL in human gastric cancer and normal tissues. The brown particles of TRAIL are distributed in the cytosol, while those of DR4 were deposited on the cell membrane and nuclear membrane, and those of FasL are visualized on cell membrane and cytosol. a, The expression of TRAIL in gastric cancer tissues. IHCx400; b, The expression of TRAIL in normal tissues. IHCx200; c, The expression of DR4 in gastric cancer tissues. IHCx200; d, The expression of FasL in gastric cancer tissues. IHCx200.

A reaction system of the following components was prepared as follows: 10X PCR buffer $2.5 \mu 1,25 \mathrm{mmol} / 1$ $\mathrm{MgCl}_{2} 2.5 \mu \mathrm{l}, 10 \mathrm{mmol} / \mathrm{l} \mathrm{dNTP} 0.5 \mu \mathrm{l}, 20 \mu \mathrm{mol} / 1 \mathrm{each}$ primer $0.5 \mu 1,2.5 \mathrm{U}$ of Taq DNA polymerase, $16 \mu 1 \mathrm{ddH}_{2} \mathrm{O}$ and $1 \mu \mathrm{l}$ of cDNA. The total reaction system volume was $25 \mu 1$. The protocol was: denaturation program $\left(95^{\circ} \mathrm{C}, 1 \mathrm{~min}\right)$, amplification and quantification programs repeated 35 times $\left(95^{\circ} \mathrm{C}\right.$ for $30 \mathrm{sec}, 60^{\circ} \mathrm{C}$ for $45 \mathrm{sec}$ and $72^{\circ} \mathrm{C}$ for $\left.1 \mathrm{~min}\right)$. The final extension step was $7 \mathrm{~min}$ at $72{ }^{\circ} \mathrm{C}$. The RT-PCR products were visualized on $1.5 \%$ agarose gels stained with ethidium bromide, and their size was determined by comparison against DNA molecular weight markers. The OD values of the PCR products were analyzed by the BLORADFLUDR-STM imaging system to indicate the expression levels of DR4 and DR5.

Statistical analysis. Quantitative variables were tested for normality, if conforming to normal distribution, the data were described as mean \pm SD and the ANOVA test or independent T-test was performed, and if not, the data were described as median with range and Spearman test was considered. For categorical data, the $\chi^{2}$ test was used to compare frequencies. The correlation between the expression of TRAIL and expression of FasL was investigated by linear regression. $\mathrm{P}<0.05$ (two-side) was considered statistically significant. SPSS 11.5 software was used for statistical analysis.

\section{Results}

Characteristics of specimens. Twenty-nine males and 5 females with gastric cancer were included. The average age was $56.71 \pm 12.82$ years. Other characteristics are listed in Table I.

Immunohistochemical staining for TRAIL, DR4, DcRl and FasL in human gastric cancer, adjacent normal tissues and distant normal tissues. In the positive tissues, the brown particles of TRAIL were distributed in the cytosol, while those of DR4 and DcR1 were deposited on the cell membrane and nuclear membrane and those of FasL were visualized in cell membrane and cytosol. The positive expression rate of TRAIL, DR4, DcR1 and FasL for gastric cancer tissues were $20.59,64.71,17.65$ and $41.18 \%$ respectively. In the adjacent normal tissues, TRAIL, DR4 and DcR 1 positive expression rates were $80,86.67$ and $46.67 \%$, respectively, while 100,100 and $61.90 \%$ in distant normal tissues, respectively (Table II, Fig. 1).

The relationships between the expression of TRAIL, DR4, DcRl and FasL and clinicopathological factors in gastric cancer tissues. There was significant relationship between the expression of TRAIL and Borrmann type of gastric cancer $(\mathrm{P}=0.039)$, and of the expression of DcR 1 and tumor location $(\mathrm{P}=0.01)$. The relationships between the expression of target proteins and other clinicopathological factors were not statistically significant (Table I). 

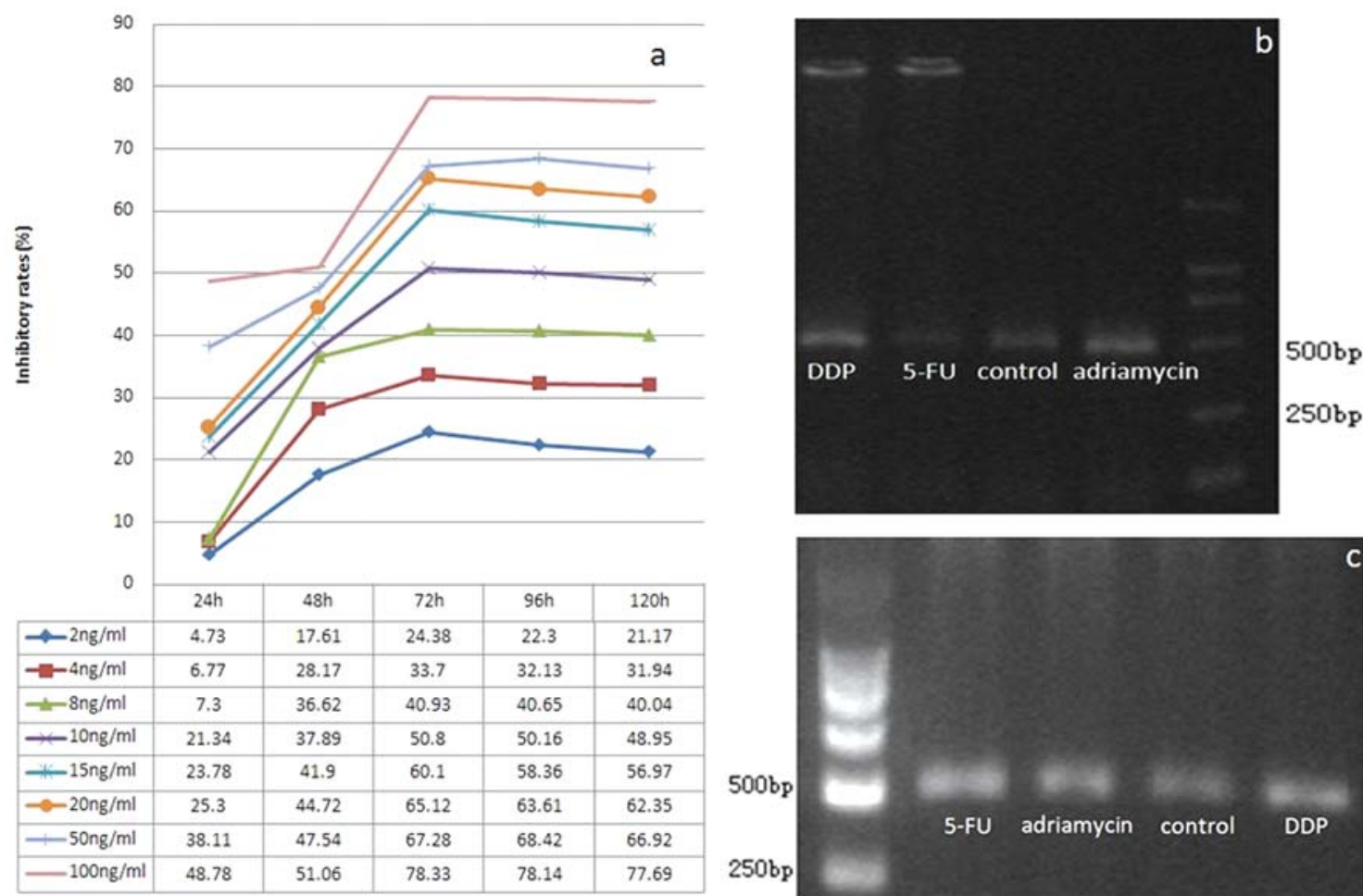

Figure 2. The impact of TRAIL with different concentrations on the growth of gastric cancer cell line and the impact of different chemotherapeutic drugs on the expression of DR4 and DR5. (a) The growth curve of the gastric cancer cell line SGC7901 according to the inhibitory rates of TRAIL with different concentrations; (b) The impact of different chemotherapeutic drugs on the expression of DR4. A single line of 506 bp for DR4; (c) The impact of different chemotherapeutic drugs on the expression of DR5. A single line of $502 \mathrm{bp}$ for DR5.

Table II. The comparisons of TRAIL, DR4, DcR1 and FasL among gastric cancer tissues, adjacent and distant normal tissues.

\begin{tabular}{|c|c|c|c|c|c|}
\hline & \multirow{2}{*}{$\begin{array}{l}\text { Gastric cancer } \\
\qquad(\mathrm{n}=34)\end{array}$} & \multirow{2}{*}{$\begin{array}{l}\text { Adjacent normal } \\
\qquad(n=15)\end{array}$} & \multirow{2}{*}{$\begin{array}{l}\text { Distant normal } \\
\text { tissues }(\mathrm{n}=21)\end{array}$} & \multicolumn{2}{|c|}{ Chi-square test } \\
\hline & & & & $\chi^{2}$-value & P-value \\
\hline \multicolumn{6}{|l|}{ TRAIL } \\
\hline Positive cases (\%) & $7(20.59 \%)$ & $12(80 \%)$ & $21(100 \%)$ & 37.5 & 0.000 \\
\hline H scores $($ mean $\pm \mathrm{SD})$ & $58.44 \pm 22.59$ & $97.67 \pm 26.72$ & $118.62 \pm 22.63$ & & \\
\hline \multicolumn{6}{|l|}{ DR4 } \\
\hline Positive cases $(\%)$ & $22(64.71 \%)$ & $13(86.67 \%)$ & $21(100 \%)$ & 10.64 & 0.005 \\
\hline $\mathrm{H}$ scores $($ mean $\pm \mathrm{SD})$ & $74.32 \pm 23.40$ & $107.33 \pm 29.63$ & $123.67 \pm 16.81$ & & \\
\hline \multicolumn{6}{|l|}{ DcR1 } \\
\hline Positive cases (\%) & $6(17.65 \%)$ & $7(46.67 \%)$ & $13(61.90 \%)$ & 11.63 & 0.003 \\
\hline $\mathrm{H}$ scores $($ mean $\pm \mathrm{SD})$ & $56.68 \pm 17.55$ & $83.00 \pm 18.69$ & $91.90 \pm 36.83$ & & \\
\hline \multicolumn{6}{|l|}{ FasL } \\
\hline Positive cases $(\%)$ & $14(41.18 \%)$ & - & - & - & - \\
\hline H scores $($ mean $\pm \mathrm{SD})$ & $65.85 \pm 24.11$ & - & - & & \\
\hline
\end{tabular}

The correlation between the expression of TRAIL and FasL. We analyzed the linear correlation between the expression of TRAIL and FasL by using the $\mathrm{H}$ scores. The results demonstrated that the correlation coefficient between the expression of TRAIL and FasL was $0.354(\mathrm{P}=0.04)$.
The impact of rh-TRAIL on the growth of the gastric cancer cell line. The $24 \mathrm{~h}$ inhibitory rates of different concentrations of rh-TRAIL mentioned above for SGC7901 were 4.73, 6.77, $7.3,21.34,23.78,25.30$ and $38.11 \%$, whereas the $48 \mathrm{~h}$ inhibitory rates were $17.61,28.17,36.62,37.89,41.90,44.72$ and $47.54 \%$. The results of other time points are summarized in Fig. 2. We established the highest concentration or longest 
Table III. The impact of different combinations of chemotherapeutic drugs and TRAIL on the growth of gastric cancer cell line.

\begin{tabular}{lcccc}
\hline & \multicolumn{4}{c}{ Inhibitory rates of SGC7901 (\%) } \\
\cline { 2 - 5 } Time & TRAIL & DDP (5-FU) & TRAIL plus DDP (TRAIL plus 5-FU) & P-value \\
\hline $24 \mathrm{~h}$ & $25.32 \pm 0.81$ & $45.34 \pm 1.40(57.45 \pm 0.38)$ & $56.04 \pm 0.45(71.87 \pm 0.45)$ & $0.000(0.000)$ \\
$48 \mathrm{~h}$ & $44.73 \pm 0.70$ & $46.47 \pm 0.64(64.10 \pm 2.27)$ & $73.95 \pm 0.47(82.28 \pm 0.46)$ & $0.000(0.000)$ \\
$72 \mathrm{~h}$ & $62.60 \pm 1.05$ & $46.68 \pm 0.52(77.81 \pm 0.42)$ & $78.51 \pm 0.70(90.86 \pm 0.35)$ & $0.000(0.000)$ \\
\hline
\end{tabular}

Table IV. The impact of different chemotherapeutic drugs on the expression of DR4 and DR5.

\begin{tabular}{lcccc}
\hline & \multicolumn{4}{c}{ The expression of DR4 (DR5) in SGC7901 } \\
\cline { 2 - 5 } & Control & DDP & 5 -FU & Adriamycin \\
\hline OD value & $0.41 \pm 0.01(0.43 \pm 0.01)$ & $0.43 \pm 0.10(0.76 \pm 0.00)$ & $0.40 \pm 0.01(0.46 \pm 0.03)$ & $0.41 \pm 0.01(0.45 \pm 0.02)$ \\
P value & & $0.006(0.000)$ & $0.144(0.036)$ & $0.937(0.174)$ \\
\hline
\end{tabular}

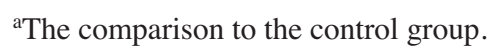

reaction time with the higher inhibitory rates tested. The inhibitory rates levelled off after culture of $72 \mathrm{~h}$.

The impact of different combinations of chemotherapeutic drugs and rh-TRAIL on the growth of the gastric cancer cell line. At 24,48 and $72 \mathrm{~h}$, the OD values of different combinations were measured (Table III). The longer the cells were cultured, the higher the inhibitory rates of rh-TRAIL were $(\mathrm{P}=0.000)$. Similar results were observed in other groups except the group treated with DDP $(\mathrm{P}=0.147)$. At each time point, the combinations of rh-TRAIL with chemotherapeutic drugs increased the inhibitory rates of rh-TRAIL or chemotherapeutic drugs $(\mathrm{P}=0.000)$.

The impact of different chemotherapeutic drugs on the expression of DR4 and DR5. Determining the specificity of the amplified product with agrose electrophoresis showed single lines of 506, 502 and 307 bp for DR4, DR5 and GAPDH respectively, which suggested the results of amplification had high specificity. With respect to the OD value of the PCR product, we found that compared to the control group, DDP facilitated the induction of the expression of DR4 and DR5 significantly $(\mathrm{P}<0.05)$, but 5 -FU influenced only the expression of DR5 significantly $(\mathrm{P}=0.036)$. Aadriamycin had no significant impacts on the expression of DR4 and DR5 ( $>0.05$ ) (Table IV).

\section{Discussion}

TRAIL mRNA is expressed in many tissues, including normal and tumor tissues. TRAIL can interact with DR4 and DR5 to induce cell apoptosis (15), but also with DcR1, DcR2 and OPG which lack an intracellular signaling domain or have a truncated death domain to inhibit the effect of DR4/ DR5 and inactivate apoptotic signal transduction upon stimulation $(9,10)$, which may be why TRAIL induces apoptosis of normal cells. TRAIL induces cell apoptosis to annihilate the tumor cells through combining with its receptors, which inspired many researchers to utilize the specific selectivity of TRAIL to induce tumor and virus-infected cell death for new anti-tumor drugs $(16,17)$.

In our study, the expression of TRAIL and its receptor DR4 in gastric cancer tissues were lower than those in normal tissues, which was in accordance with the fact that apoptosis inhibition in cancers. DcR1 was also lower than that in normal tissues, in contrast with others (18). This may due to the influence of the complicated signal pathways. With respecting to the clinicopathological factors, the expression of TRAIL seems to correlate with Borrmann type of gastric cancer $(\mathrm{P}=0.039)$ and the expression of $\mathrm{DcR} 1$ is related to the tumor location. Relationships between the expression of target proteins and other clinicopathological factors were insignificant. However, the relatively small number of the specimens may bias the outcome. Further large scale research is needed.

Regarding the complex mechanism of TRAIL to induce apoptosis, although many aspects remain unclear, many lines of research have suggested the combinations of TRAIL with DR4 and DR5 could activate the intracellular FAS-associated death domain (FADD) to promote the caspase cascade, inducing cell death $(19,20)$. DcR1 and DcR2 could not activate FADD to lead to apoptosis (21). Yang et al demonstrated that the anticancer potency of TRAIL was associated with the increased expression of caspase 3 in gastric cancer cells (22). After the 5 Gy X-irradiation in gastric cancer cell lines MKN45 and MKN28, the subsequent treatments with TRAIL increased the formation of active fragment p20 of caspase 3 followed by the induction of apoptosis (23). Kanehara et al reported that caspase- 8 correlated well with the anticancer effect of TRAIL in gastric 
cancer cells (24). Blocking the activation of caspase- 8 completely inhibited TRAIL-induced apoptosis (25). In addition, other signal pathways, such as JNK and NF-кB (26) pathways may play a role in the apoptosis induction of TRAIL. Interestingly, not only did TRAIL induce tumor cell death, but also promoted further invasion and/or metastasis of carcinoma. Koyama et al reported $\mathrm{TRAIL}^{+}$and DcR2 ${ }^{+}$ metastatic carcinoma from malignant ascites have resistance to DR4/DR5-induced apoptosis, and also might take the TRAIL-mediated counterattack against activated $\mathrm{CD}^{+} \mathrm{T}$ cells, which would neutralize host immune responses at the effector phase and escape from immune attack to accelerate further invasion and/or metastasis of carcinoma (27).

FasL, which belongs to the tumor necrosis factor (TNF) family, induces apoptotic death of cells expressing its cell surface receptor (Fas) through transmitting the death signal into cells (28). Fas/FasL system has a different signal pathway from TRAIL pathway to induce apoptosis (29). In our study, the positive expression rate of FasL was $41.18 \%$ (14/34) with a correlation coefficient of 0.354 to the expression of TRAIL. Although the correlation coefficient could not indicate the correlation of the expression, it has a trend suggesting there may be a functional connection, which was supported by Martin et al (30). The exact relationship between the two pathways and its clinical significance need to be explored further.

The utilization of TRAIL could induce tumor cell deaths, including gastric cancer $(7,31,32)$. In our study, we applied MTT method to detect the inhibitory rates of rh-TRAIL with different concentration to the SGC7901. The results showed that the concentration and culture time increased, the inhibitory effect was also enhanced. The inhibitory rates levelled off after culture of $72 \mathrm{~h}$.

Chemotherapeutic drugs are important adjuvant treatments for gastric cancer and could be used with TRAIL to overcome TRAIL resistance (33). DDP and 5-FU have been widely used in the treatment of gastric cancer. Conventional chemotherapy can induce apoptosis as a secondary consequence of inflicting cell damage (31). Pan et al (34) found combination of TRAIL-carrying adenoviral vector with cisplatin showed an apparent synergistic cytotoxicity in cancer cells, and at the same time significantly abolished the toxicity in normal cells by reducing the dosage. Concomitant 5-FU and TRAIL therapy enhanced apoptotic activity and reduced the requirement for 5-FU that ultimately results in minimizing risks for systemic side effects $(35,36)$. Our results confirmed the previous results. In our study, the inhibitory rates of combinations of TRAIL plus chemotherapeutic drugs were higher than TRAIL alone and chemotherapeutic drug alone $(\mathrm{P}=0.000)$, which suggested that concomitant TRAIL and chemotherapeutic drugs could shed light on the synergy effect in inducing tumor cell apoptosis. Shamimi-Noori et al (37) demonstrated that DDP interacted with TRAIL to mediate profound activation of caspase cascade via recruitment of the mitochondriadependent death signaling pathway, whereas the increased effectiveness of caspase- 8 recruitment to and activation at the death-inducing signaling complex (DISC) and the consequent shift in the ratio of caspase- 8 to cellular FLICEinhibitory protein (cFLIP) at the DISC may be a potential mechanism for TRAIL sensitization by 5-FU (38). In addition, some other drugs, such as phosphatidylinositol 3kinase inhibitor, and non-steroidal anti-inflammatory drugs also enhanced the apoptotic effect of TRAIL $(39,40)$.

Chemotherapeutic drugs sensitize cancer cells to TRAIL-mediated apoptosis concomitant with up-regulation of DR5 expression (41-43). In our study, we employed RTPCR to determine the expression of DR4 and DR5 after dealing with chemotherapeutic drugs. DDP and 5-FU, rather than adriamycin, were prone to increase the expression of DR4 and/or DR5 significantly, which may indicate that the enhanced apoptotic effect of TRAIL when combined with chemotherapeutic drugs was due to the increased expression of DR4 and DR5 induced by drugs. Also the exception of adriamycin may be accounted for by the different sensitivity of cancer cells to different chemotherapeutic drugs, but discrepancy also exists. Dong et al (44) reported that the high expression of DR4 and DR5 were associated with poor response to chemotherapy in patients with ovarian carcinoma at disease recurrence. Therefore, the contribution of death receptors when given with chemotherapeutic drugs in the treatment of cancers also waits further investigation.

In conclusion, the expression of TRAIL and its receptors were lower in gastric cancer than normal tissue, and the apoptosis-inducing effect of rh-TRAIL was enhanced when concomitant with chemotherapeutic drugs. Our results need to be determined in further large scale research.

\section{Acknowledgements}

This study was supported by Multidisciplinary Treatment Project of Gastrointestinal Tumors, West China Hospital, Sichuan University, P.R. China, and Scientific Research Foundation of Health Department (No. 030177), Sichuan Province, P.R. China. We thank Professor Kai-Xuan Yang (West China Second Hospital of Sichuan University) and Bing Wei (West China Hospital, Sichuan University) for their professional pathologic technology support.

\section{References}

1. Jemal A, Siegel R, Ward E, Hao Y, Xu J, Murray T and Thun MJ: Cancer statistics, 2008. CA Cancer J Clin 58: 71-96, 2008.

2. National Comprehensive Cancer Network: NCCN Clinical Practice Guidelines in Oncology ${ }^{\mathrm{TM}}$ Gastric Cancer V.1.2008. URL: http://www.nccn.org/professionals/physician_gls/ PDF/gastric.pdf. (accessed July 15, 2008)

3. Blank VC, Peña C and Roquin LP: A cyclic chimeric interferonalpha2b peptide induces apoptosis in tumor cells. Cancer Biol Ther 6: 1787-1793, 2007.

4. Das T, Sa G, Hilston C, et al: GM1 and tumor necrosis factoralpha, overexpressed in renal cell carcinoma, synergize to induce T-cell apoptosis. Cancer Res 68: 2014-2023, 2008.

5. Yada A, Yazawa M, Ishida S, Yoshida H, Ichikawa K, Kurakata S and Fujiwara K: A novel humanized anti-human death receptor 5 antibody CS-1008 induces apoptosis in tumor cells without toxicity in hepatocytes. Ann Oncol 19: 1060-1067, 2008.

6. Tatsumi N, Oji Y, Tsuji N, et al: Wilms' tumor gene WT1shRNA as a potent apoptosis-inducing agent for solid tumors. Int J Oncol 32: 701-711, 2008

7. Ashkenazi A, Pai RC, Fong S, et al: Safety and antitumor activity of recombinant soluble Apo2 ligand. J Clin Invest 104: 155-162, 1999.

8. Wiley SR, Schooley K, Smolak PJ, et al: Identification and characterization of a new member of the TNF family that induces apoptosis. Immunity 3: 673-682, 1995. 
9. Sheridan JP, Marsters SA, Pitti RM, et al: Control of TRAILinduced apoptosis by a family of signaling and decoy receptors. Science 277: 818-821, 1997.

10. Emery JG, McDonnell P, Burke MB, et al: Osteoprotegerin is a receptor for the cytotoxic ligand TRAIL. J Biol Chem 273: 14363-14367, 1998

11. Abou El Hassan MA, Mastenbroek DC, Gerritsen WR, Giaccone $\mathrm{G}$ and Kruyt FA: Overexpression of Bcl2 abrogates chemo- and radiotherapy-induced sensitisation of NCI-H460 non-small-cell lung cancer cells to adenovirus-mediated expression of full-length TRAIL. Br J Cancer 91: 171-177, 2004.

12. Japanese Gastric Cancer Association: Japanese Classification of Gastric Carcinoma - 2nd English Edition. Gastric Cancer 1: 10-24, 1998.

13. Fernandes BJ, Yao XY, Hao Y, Sutherland DJ, Sidlofsky S and Blackstein ME: DNA content and estrogen receptors in primary carcinoma of the breast. Can J Surg 34: 349-355, 1991

14. Griffith TS, Chin WA, Jackson GC, Lynch DH and Kubin MZ: Intracellular regulation of TRAIL-induced apoptossi in human melanoma cells. J Immunol 161: 2833-2840, 1998.

15. Pan G, O' Rourke K, Chinnaiyan AM, Gentz R, Ebner R, Ni J and Dixit VM: The receptor for the cytotoxic ligand TRAIL. Science 276: 111-113, 1997

16. Griffith TS and Lynch DH: TRAIL: a molecule with multiple receptors and control mechanisms. Curr Opin Immunol 10: 559-563, 1998

17. Walczak H, Miller RE, Ariail K, et al: Tumoricidal activity of tumor necrosis factor-related apoptosis-inducing ligand in vivo. Nat Med 5: 157-163, 1999.

18. Sheikh MS, Huang Y, Fernandez-Salas EA, et al: The antiapoptotic decoy receptor TRID/TRAIL-R3 is a p53regulated DNA damage-inducible gene that is overexpressed in primary tumors of the gastrointestinal tract. Oncogene 18: 4153-4159, 1999

19. Kischkel FC, Lawrence DA, Chuntharapai A, Schow P, Kim KJ and Ashkenazi A: Apo2L/TRAIL-dependent recruitment of endogenous FADD and caspase- 8 to death receptors 4 and 5 . Immunity 12: 611-620, 2000.

20. Xu SQ and El-Deiry WS: p21(WAF1/CIP1) inhibits initiator caspase cleavage by TRAIL death receptor DR4. Biochem Biophys Res Commun 269: 179-190, 2000.

21. Pan G, Ni J, Wei YF, Yu G, Gentz R and Dixit VM: An antagonist decoy receptor and a death domain-containing receptor for TRAIL. Science 277: 815-818, 1997.

22. Yang LQ, Fang DC, Wang RQ and Yang SM: Effect of NFkappaB, survivin, Bcl-2 and Caspase 3 on apoptosis of gastric cancer cells induced by tumor necrosis factor related apoptosis inducing ligand. World J Gastroenterol 10: 22-25, 2004.

23. Hamasu T, Inanami O, Asanuma T and Kuwabara M: Enhanced induction of apoptosis by combined treatment of human carcinoma cells with $\mathrm{X}$ rays and death receptor agonists. J Radiat Res 46: 103-110, 2005.

24. Kanehara I, Nakata B and Hirakawa K: Caspase- 8 is scarcely silenced and its activity is well correlated with the anticancer effect of tumor necrosis factor-related apoptosis-inducing ligand in gastric cancer cells. Oncol Rep 14: 1249-1253, 2005.

25. Nam SY, Jung GA, Hur GC, Chung HY, Kim WH, Seol DW and Lee BL: Upregulation of FLIP(S) by Akt, a possible inhibition mechanism of TRAIL-induced apoptosis in human gastric cancers. Cancer Sci 94: 1066-1073, 2003.

26. Kimberley FC and Screaton GR: Following a TRAIL: update on a ligand and its five receptors. Cell Res 14: 359-372, 2004.

27. Koyama S, Koike N and Adachi S: Expression of TNF-related apoptosis-inducing ligand (TRAIL) and its receptors in gastric carcinoma and tumor-infiltrating lymphocytes: a possible mechanism of immune evasion of the tumor. J Cancer Res Clin Oncol 128: 73-79, 2002.
28. Nagata S and Golstein P: The Fas death factor. Science 267: 1449-1456, 1995

29. Suda T, Takahashi T, Golstein P and Nagata S: Molecular cloning and expression of the Fas ligand, a novel member of the tumor necrosis factor family. Cell 75: 1169-1178, 1993.

30. Martin JH, Potthoff A, Ledig S, et al: Effect of H. pylori on the expression of TRAIL, FasL and their receptor subtypes in human gastric epithelial cells and their role in apoptosis. Helicobacter 9: 371-386, 2004.

31. Ashkenazi A, Holland P and Eckhardt SG: Ligand-based targeting of apoptosis in cancer: the potential of recombinant human apoptosis ligand 2/Tumor necrosis factor-related apoptosis-inducing ligand (rhApo2L/TRAIL). J Clin Oncol 26: 3621-3630, 2008

32. Wei XC, Wang XJ, Chen K, Zhang L, Liang Y and Lin XL: Killing effect of TNF-related apoptosis inducing ligand regulated by tetracycline on gastric cancer cell line NCI-N87. World J Gastroenterol 7: 559-562, 2001.

33. Meurette O, Fontaine A, Rebillard A, Le Moigne G, Lamy T, Lagadic-Gossmann D and Dimanche-Boitrel MT: Cytotoxicity of TRAIL/anticancer drug combinations in human normal cells. Ann NY Acad Sci 1090: 209-216, 2006.

34. Pan Q, Liu B, Liu J, Cai R, Wang Y and Qian C: Synergistic induction of tumor cell death by combining cisplatin with an oncolytic adenovirus carrying TRAIL. Mol Cell Biochem 304: 315-323, 2007.

35. Lee KC, Hamstra DA, Bhojani MS, Khan AP, Ross BD and Rehemtulla A: Noninvasive molecular imaging sheds light on the synergy between 5-fluorouracil and TRAIL/Apo2L for cancer therapy. Clin Cancer Res 13: 1839-1846, 2007

36. Shimoyama S, Mochizuki Y, Kusada O and Kaminishi M: Supra-additive antitumor activity of 5FU with tumor necrosis factor-related apoptosis-inducing ligand on gastric and colon cancers in vitro. Int J Oncol 21: 643-648, 2002.

37. Shamimi-Noori S, Yeow WS, Ziauddin MF, et al: Cisplatin enhances the antitumor effect of tumor necrosis factor-related apoptosis-inducing ligand gene therapy via recruitment of the mitochondria-dependent death signaling pathway. Cancer Gene Ther 15: 356-370, 2008.

38. Ganten TM, Haas TL, Sykora J, et al: Enhanced caspase-8 recruitment to and activation at the DISC is critical for sensitisation of human hepatocellular carcinoma cells to TRAIL-induced apoptosis by chemotherapeutic drugs. Cell Death Differ 11: S86-S96, 2004

39. Opel D, Westhoff MA, Bender A, Braun V, Debatin KM and Fulda S: Phosphatidylinositol 3-kinase inhibition broadly sensitizes glioblastoma cells to death receptor- and druginduced apoptosis. Cancer Res 68: 6271-6280, 2008.

40. Gaiser T, Becker MR, Habel A, Reuss DE, Ehemann V, Rami A and Siegelin MD: TRAIL-mediated apoptosis in malignant glioma cells is augmented by celecoxib through proteasomal degradation of survivin. Neurosci Lett 442: 109-113, 2008.

41. Arts HJ, de Jong S, Hollema H, ten Hoor K, van der Zee AG and de Vries EG: Chemotherapy induces death receptor 5 in epithelial ovarian carcinoma. Gynecol Oncol 92: 794-800, 2004.

42. Shankar S, Chen X and Srivastava RK: Effects of sequential treatments with chemotherapeutic drugs followed by TRAIL on prostate cancer in vitro and in vivo. Prostate 62: 165-186, 2005.

43. Baritaki S, Huerta-Yepez S, Sakai T, Spandidos DA and Bonavida B: Chemotherapeutic drugs sensitize cancer cells to TRAIL-mediated apoptosis: up-regulation of DR5 and inhibition of Yin Yang 1. Mol Cancer Ther 6: 1387-1399, 2007.

44. Dong HP, Kleinberg L, Silins I, et al: Death receptor expression is associated with poor response to chemotherapy and shorter survival in metastatic ovarian carcinoma. Cancer 112: 84-93, 2008. 